\title{
Impact of National Cultures on Automotive Sector After Sales Services Perception
}

DOI: 10.7595/management.fon.2017.0014

\begin{abstract}
This article clarifies the impact of national culture in the after sales service in the automotive sector. Introduction and objectives: after-sales services have become of paramount importance in the automobile industry. However, they are not sufficiently researched, particularly inemerging markets. Here an academic gap exists because, within the automotive industry research literature, culture is a widely neglected issue. Thus no explicit knowledge can be applied regarding emerging markets service demand behaviour, which might be a crucial point, as in some of these countries culture is different from the western culture. Methods: The research is based on a survey carried out among Chinese premium brand automotive customers. Results: It shows which individual level values are causal and positively contribute to the perception of service quality and loyalty behaviour by customers. Conclusion: The articleprovides a guideline to how the entire process chain of after-sales services could be researched and applies successfully the individual level value theory by Schwartz. Implications and research limitation: Brand loyalty is well explained by perceived service quality significantly leading to after-sales service satisfaction, which itself is a strong predictor of workshop loyalty. Moreover, workshop loyal customers are likewise significantly brand loyal. Finally, the influence of culture is empirically verified with the one exception of after-sales service satisfaction.
\end{abstract}

Keywords: National culture, after-sales services, brand loyalty, PLS-SEM, individual level value theory

JEL classification: M14, L62, L81

\section{Introduction}

The automobile industry is one of the most global relevant industries. Consequently, ample literature has dealt with it. Nevertheless, not every aspect of the value chain has been researched with the same or required effort. Traditionally, sales, product design and operational issues are the most intensely emphasized topics, which is most likely a result of the car manufacturer's dominant status. Manufacturers of original equipment (OEMs) are considered as system leaders (DiezandReindl, 2005, p. 61), which for long have been predominantly engaged in producing and selling. The focus, in the industry, has migrated actually towards services - and likewise services research - has become increasingly important (Diez, 2009, pp. 109; Reichhuber, 2010, pp.89-103;; Saccani, Songini, and Gaiardelli, 2006, p. 262).

In this context, after-sales services have an outstanding role, since - even across industries - they are considered to be high-profit margin performances, mostly more profitable as the core product itself (Cavalieri, Gaiardelli, and lerace, 2007, p. 437; Goffin,1999; Wise and Baumgartner, 1999). Moreover, various studies suggest that these services foster further objectives, such as increasing customer satisfaction and brand loyalty (Hünecke, 2012; Saccani et al., 2006; Huber and Herrmann, 2001). Hence achieving competitive advantageand differentiation (Goffinand New, 2001; Asugman, Johnson, and Mc Cullough, 
1997; Hull and Cox, 1994) or having the capability to increase brand image (Cavalieri et al., 2007, Saccani et al., 2006, Gallagher, Mischke, and Rogers, 2005).

Besides, the need for further research in the after-sales area (Jönke, 2012, pp. 145; Gebauer, Ren, Valtakoski and Reinoso, 2012, p. 123.) and the fact that published research has been carried out in, mostly on mature, saturated Western markets, and the fact that related enterprises, due to their origin, suffer from a distorted self-perception (bias) must be taken into account.

Another relevant issuethat is mostly neglected in the automotive marketing, is the influence of culture on service demand behaviour, in spite of the scarce published research (Löffler and Dekker, 2012, p.405; Wang, 2011, p. 100; Gudergan, 2010, p. 251; Zhang, Beatty, and Walsh, 2008, p. 222, Gong, 2003, p. 379; Asugman et al., 1997, p. 26). Some authors such as Zhang et al. (2008, pp. 211 et seq.) accurately review applied cultural studies within the services marketing literature, Thereby claiming to go beyond Hofstede because when culture is analyzed almost only the Hofstede dimensions are used. Thus, they also acknowledge the importance of the customer/service provider relationship, which takes place at automobile workshops.

To address the sum of the mentioned research gaps, this paper elaborates an innovative research model, which examines the whole after-sales service process chain of automobile manufacturers, precisely considering cultural effects as causal determinants. In doing so, an empirical (consumer based) success factor research is conducted thatfocuses on German premium car manufacturers in China.

China has been selected as a research object because it is the leading automotive market globally for German OEMs (VDA, 2015, p. 20.). in total, German brands possess the second largest market share in China, where they capture around $80 \%$ of the premium market segment (CAAM, 2013; Sha, Huang, and Gabardi, 2013, p.5). Besides its market significance, China represents a collectivistic Asian culture, which is considered to be completely different from Western cultures or markets, with very heterogeneous consumer segments and behaviour patterns (Wang, Liao, and Hein, 2012, p. 10; Knörle, 2011, p. 7; Köll, 2009; Xin-an et al., 2008, p. 377; Cui and Liu, 2001, p. 101). Thereby, this research is limited to the urban living Chinese who have a service experience in brand workshops of Audi, BMW or Mercedes-Benz.

This paper is organized in the following way. The initial section including and discussing the conceptual and theoretical background of the study serves as an introduction.In the following chapter, the article describes the automotive after-sales service success chain (field objective of the study) and then presentsthe theory of individual level values by Schwartz, on which this research has been based. The fourth section proposes a research model and the corresponding hypotheses. The research method has been described subsequently and the results are discussed with a final section summarizing the article conclusions.

\section{Conceptual and Theoretical Background of the Study}

\subsection{Defining a Success Indicator}

This research aims to uncover cause-effect relationships within the after-sales business of German OEMs in China, by considering cultural influences and the effects on the companies' success. Thus, it is important to define what we understand by success.

Within services marketing and brand management, brand loyalty is understood as a central objective (Esch, 2010, p. 72), with the increasing recognition that it is the ultimate purpose to which customer satisfaction has to be measured (Sivadas and Backer-Prewitt, 2000: 75). Knörle (2011, p. 19.) and investigates specifically brand loyalty in China and likewise opts for it, in order to define success, because brand loyalty generates steady revenues (fosters repurchases, creates emotional switching barriers, customers are less attracted by alternatives). Additionally, it creates revenue growth (increases purchase frequency, encourages the willingness for cross-buying, increases word-of-mouth recommendations), and, finally, brand loyalty raises the profitability (achieving price premiums, increases advertisement efficiency).

As a result, brand loyalty has been selected as the success indicator in this paper. Thereby, it must be considered that the Chinese premium car market is still predominantly a first buyer market.Because of this, 
a behavioural measurement approach based on actual repurchases would lead to bias, as a significant amount of car users would be excluded from the research. Thus, actual service customers, who are also potential buyers, are focused upon and therefore the repurchase, and recommendation intention is measured.

\subsection{The Automotive after-sales Service Success Chain}

When considering the target system of service enterprises, Meffert and Bruhn (2009, pp. 139 et seq.) argue that success is dependent on three target dimensions: the so-called enterprise-directed, customer-directed and staff-directed target dimensions. Due to the consumer focus of this research, the customer-directed target dimension is the most relevant. Here, they state that this dimension is directly linked to the determinants of purchasing behaviour, which is why they can be considered as the key influencing factors of service marketing.

Customer related objectives can be differentiated into three topic groups, psychological (e.g., quality perception and customer satisfaction), behavioural (e.g., repurchase and recommendation behaviour) and economical (e.g., customer value) objectives. These three goals are linked to each other, as expressed by the success chain (Meffert and Bruhn, 2009, p. 91).

This success chain within service sectors can be specified to the automobile after-sales service business as shown in Figure 1.

Effect Factors of Consumer Behaviour in the Service Sector along the Success Chain

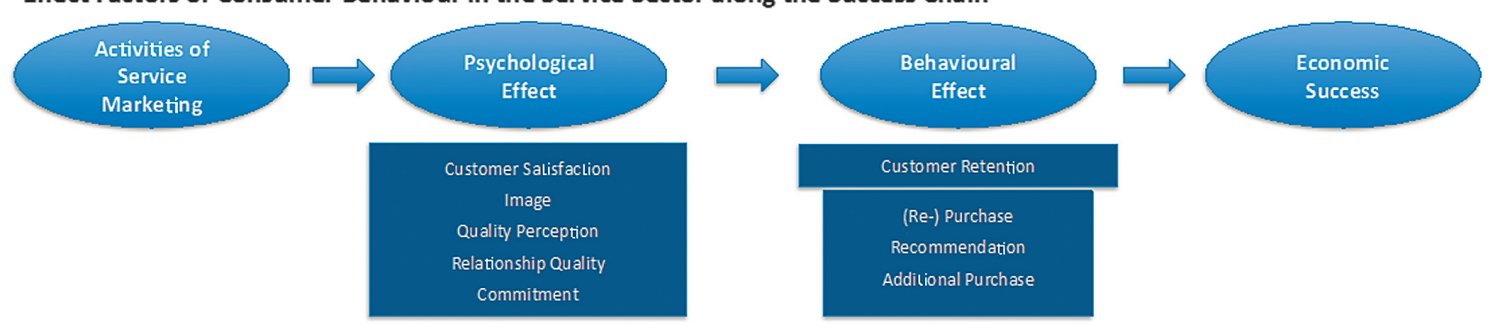

Customer Directed After-sales Service Objectives within the Success Chain

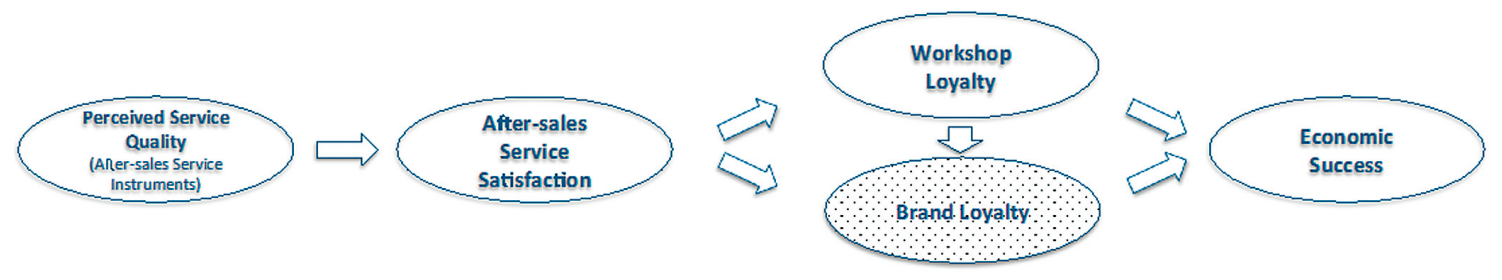

Figure 1: Success Chains of Consumer Behaviour and Automotive after-sales Service. Reference: Author's illustration referring to Meffertand Bruhn, 2009, p. 91.

Consequently, the key constructs of the research model about after-sales services are: (a) perceived service quality, (b) after-sales service satisfaction, (c) workshop loyalty and (d) brand loyalty. These constructs, in general, are considered as being significant and linked, as various Western and Chinese studies have shown (see Table 1). The literature dealing with the mentioned after-sales related constructs widely acknowledges the relationships of the success chain, as well as the positive contribution of the indicated exogenous constructs, towards brand loyalty (see Table 1). In this article, these relationships are formulated as hypotheses. However, besides the general acceptance across industries, they have not been tested specifically in the Chinese automobile after-sales business. This paper overcomes this limitation via an empirical testing of these hypotheses, which are proposed in the manner of: the higher the exogenous construct, the higher the endogenous construct. 
These hypotheses, as well as the corresponding academic literature, are presented as a detailed overview in Table 1.

Table 1: Overview of Hypotheses

\begin{tabular}{|c|c|c|}
\hline \multicolumn{3}{|c|}{ Summary of Hypotheses } \\
\hline No. & Hypothesis & Relevant Literature \\
\hline $\mathrm{H} 1$ & $\begin{array}{l}\text { The higher the after-sales service satisfaction, the } \\
\text { higher the workshop loyalty. }\end{array}$ & $\begin{array}{l}\text { Hünecke, 2012: 127; Hättich, 2009: 213; Bei \& Chiao, } \\
\text { 2001: 138; Devaraj et al., 2001: } 434 \text { f.; Bloemer \& } \\
\text { Pauwels, 1998: 82; Bloemer \& Lemmink, 1992: } 359 \\
\text { Additional input from service industries in China: } \\
\text { Li et al., 2008: } 455 \text { f.; Deng et al., 2010: 295; Yim et al., } \\
\text { 2008: } 751\end{array}$ \\
\hline $\mathrm{H} 2$ & $\begin{array}{l}\text { The higher the workshop loyalty, the greater the } \\
\text { brand loyalty. }\end{array}$ & $\begin{array}{l}\text { Hünecke, 2012: 128; Hättich, 2009: 213; Bloemer \& } \\
\text { Lemmink, 1992: } 359\end{array}$ \\
\hline H3 & $\begin{array}{l}\text { The higher the perceived service quality, the } \\
\text { higher the after-sales service satisfaction }\end{array}$ & $\begin{array}{l}\text { Hünecke, 2012: 147; Shuqin \& Gang, 2012: 177; Hättich, } \\
\text { 2009: 213; Bei \& Chiao: 2001: } 136 \text { et seq.; Devaraj et al., } \\
\text { 2001: } 434 \\
\text { Additional input from service industries in China: } \\
\text { Deng et al., 2010: 296; Yim et al., 2008: 751. }\end{array}$ \\
\hline \multirow[t]{2}{*}{$\mathrm{H} 4$} & $\begin{array}{l}\text { Perception of service quality is significantly } \\
\text { influenced by culture. }\end{array}$ & Knörle, 2011: 203 et seq. \\
\hline & \multicolumn{2}{|c|}{$\begin{array}{l}\text { Perception of service quality is significantly influenced by: conformity (CON); tradition (TRA); benevolence } \\
\text { (BEN); universalism (UNI); self-direction (SE-D); stimulation (STI); hedonism (HED); achievement (ACH) } \\
\text { power (POW); security (SEC). }\end{array}$} \\
\hline \multirow[t]{2}{*}{ H5 } & \begin{tabular}{|l|}
$\begin{array}{l}\text { After-sales service satisfaction is significantly } \\
\text { influenced by culture. }\end{array}$ \\
\end{tabular} & $\begin{array}{l}\text { Van Birgelen et al., 2002: } 60 \text { f.; Reimann et al., 2008: 70; } \\
\text { Frank et al., 2013: } 2402 \mathrm{f.}\end{array}$ \\
\hline & \multicolumn{2}{|c|}{$\begin{array}{l}\text { After-sales service satisfaction is significantly influenced by: (CON); (TRA); (BEN); (UNI); (SE-D); (STI); } \\
(\mathrm{HED);} \mathrm{(ACH);} \mathrm{(POW);} \mathrm{(SEC).}\end{array}$} \\
\hline \multirow[t]{2}{*}{$\mathrm{H} 6$} & Brand loyalty is significantly influenced by culture & $\begin{array}{l}\text { Lam, 2007: 15; Thompson et al., 2014: 2443; Yoo, } 2008 \text { : } \\
53 \mathrm{f} \text {. }\end{array}$ \\
\hline & \multicolumn{2}{|c|}{$\begin{array}{l}\text { Brand loyalty is significantly influenced by: (CON); (TRA); (BEN); (UNI); (SE-D); (STI); (HED); (ACH); (POW); } \\
\text { (SEC). }\end{array}$} \\
\hline $\mathrm{H} 7$ & $\begin{array}{l}\text { Workshop loyalty is significantly influenced by } \\
\text { culture }\end{array}$ & No directly related studies available. \\
\hline & $\begin{array}{l}\text { Workshop loyalty is significantly influenced by: (C } \\
\text { (POW); (SEC). }\end{array}$ & 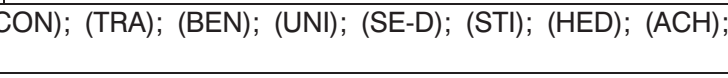 \\
\hline
\end{tabular}

Thereby, highly appropriate automobile after-sales particular literature is shown. As the hypotheses have not been tested industry specific in China, the list is supported by China-specific studies originating across industries.

\subsection{The Causal Influence of Cultural Values}

In this paper, culture is considered as a significant stream of influences, which presumably affects the entire after-sales business, or, as Zhang et al. (2008, p. 212.) conclude, every consumer service experience dimension (expectation, evaluation, reaction). Likewise, intercultural researchers agree, when they argue, thatmost elements of consumer behaviour are culture-bound, (...). (De Mooij, 2014,.53) or that culture (..), as a significant independent variable, determinesconsumer behavior. (Emrich, 2007, pp. 35; Emrich, 2014, pp. 45).

However, culture is not consistently defined, and various operationalisation approaches exist. As mentioned earlier, mostly the Hofstede dimensions are applied, but this paper claims to be more innovative. To achieve this, the concept of culture is introduced inFigure 2, considering that this conceptual approach by Osgood (1951)has been widely accepted in the field (Emrich, 2014, p. 31; Meffert et al., 2010, p. 107; Müller andGelbrich, 2004, p. 68). 


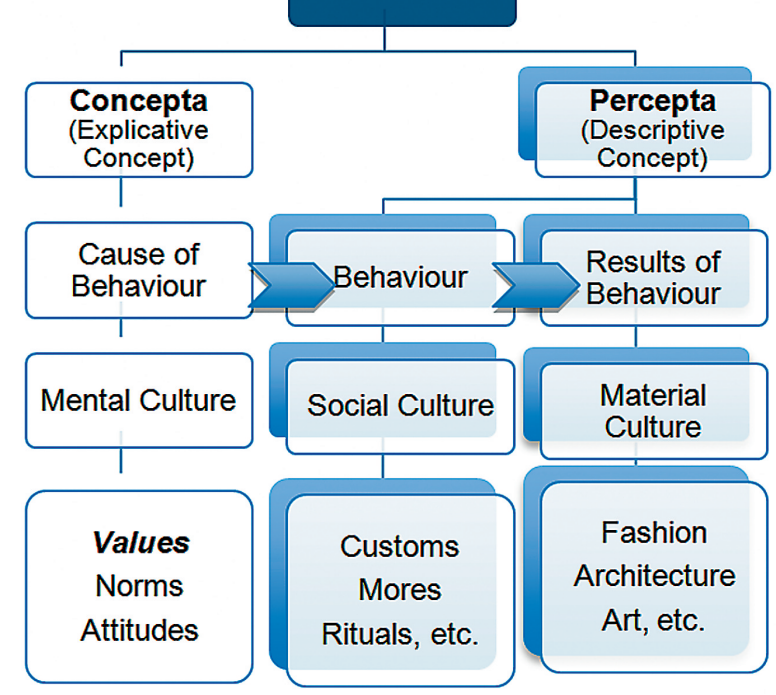

Figure 2: Concept of Culture. Reference: Authors illustration referring to Meffertand Bruhn, 2010, p. 108; Osgood, 1951, pp. 202 et seq.

Here, values are described as a crucial manifestation of the layer mental culture. As represented by the arrows, values or likewise norms and attitudes are causal for behaviour (Osgood, 1951, pp. 202 et seq.), and thus a possible anchor to operationalize culture. The significance of values is undoubted, because values are considered as a core element of culture (Engelen and Brettel, 2011, p. 75; Schwartz, 2006, pp. 138 et seq.; Müller and Gelbrich, 2004: 303; Hofstede, 1997, pp. 7 et seq.) guiding choices and actions (Srnka, 2005, p. 78; Triandis, 1994, p.111; Schwartz, 1992, p. 2).

Given that values are causal, it is possible to operationalize them as exogenous variables, which is a powerful kind of application to reach the objective, to explain how Chinese culture affects the after sales process chain.

If values are of interest, the theory of individual level or core values by Schwartz (1992) is most closely related. Recently, it is considered to be one of the best theoretically and empirically grounded value theories globally (Cieciuch and Davidov, 2012, p. 37). However, Schwartz is a psychologist, which might be the cause why his approach is rarely applied in marketing research (Zhang et al., 2008, p. 213).

\subsection{Theory of Individual Level Values by Schwartz}

Schwartz defines (...) fundamental values as trans-situational goals, varying in importance, that serve as guiding principles in the life of a person or group.(Schwartz et al., 2011, p. 664; Schwartz, 1992, pp. 1 et seq.) Schwartz identified a comprehensive set of ten individual level values, which are relevant in every society. Theyare ordered around a motivational circle and organized as a coherent system. The circular structure reflects a dynamic relation among the values, which can be expressed as conflicts and congruities, where relatively seen, values next to each other are fairly similar in contrast to values arranged opposite to one another (Davidov, Schmidt, and Schwartz, 2006, p. 423; Schwartz, 2003, pp. 268 et seq.). Additionally, they can also be consolidated as four higher order values on two orthogonal dimensions, as shown in . 


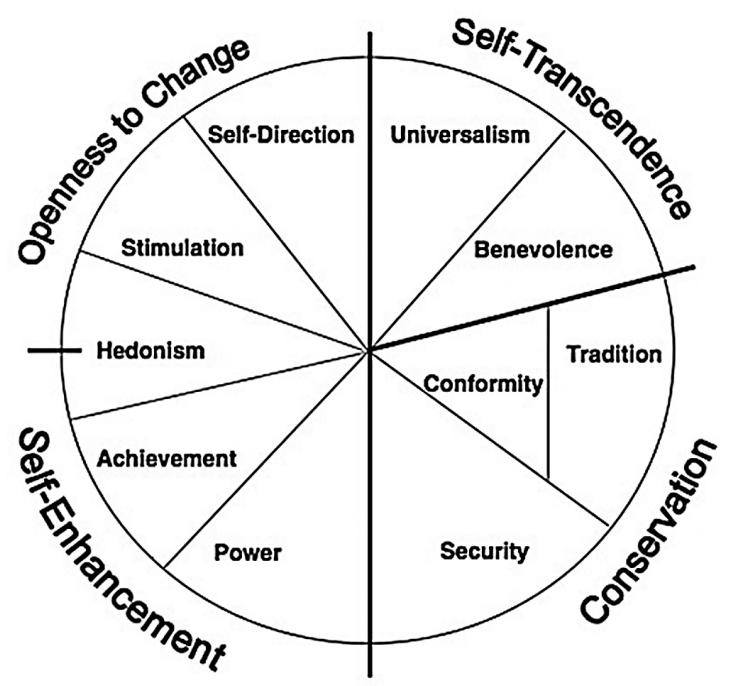

Figure 3: Structural Relation of the Basic Values (Davidov et al., 2008, p. 425.)

Notably, this theory enables causal within-country analysis, in contrast to the mostly used national comparisons that only can show differences, but cannot directly explain the underlying causality.To this, various studies have shown important influences of individual value priorities towards attitudes and behavior such as political activism or voting (Davidov et al., 2008, p. 441). As a result of the mentioned arguments, the ten individual level values are used as exogenous constructs, because this methodology fits perfectly to the purpose of this paper.

The ten motivationally distinct primary values are presented in detail with the underlying conceptual definition in the following list as per Table 2.

Table 2: Conceptual Definition of Basic Values (Schwartz, 1994, p. 22.)

\begin{tabular}{|l|l|}
\hline Value & Conceptual Definition \\
\hline Self-direction & Independent thought and action-choosing, creating, exploring \\
\hline Stimulation & Excitement, novelty, and challenge in life \\
\hline Hedonism & Pleasure and sensuous gratification for oneself. \\
\hline Achievement & $\begin{array}{l}\text { Personal success through demonstrating competence according to social } \\
\text { standards }\end{array}$ \\
\hline Power & $\begin{array}{l}\text { Social status and prestige, control or dominance over people and } \\
\text { resources }\end{array}$ \\
\hline Security & $\begin{array}{l}\text { Safety, harmony, and stability of society, of relationships, and of self } \\
\text { Conformity }\end{array} \begin{array}{l}\text { Restraint of actions, inclinations, and impulses likely to upset or harm } \\
\text { others and violate social expectations or norms }\end{array}$ \\
\hline Tradition & $\begin{array}{l}\text { Respect, commitment, and acceptance of the customs and ideas that } \\
\text { traditional culture or religion provides }\end{array}$ \\
\hline Benevolence & $\begin{array}{l}\text { Preservation and enhancement of the welfare of people with whom one is in } \\
\text { frequent personal contact }\end{array}$ \\
\hline Universalism & $\begin{array}{l}\text { Understanding, appreciation, tolerance and protection for the welfare of all } \\
\text { people and nature }\end{array}$ \\
\hline
\end{tabular}

To operationalize these values, various approaches have been anticipated (see for instance CieciuchandDavidov, 2012, pp. 37 et seq.). Thereof, a Portrait Values Questionnaire (PVQ) approach with 21 items is used in this article, sinceit is extremely time efficient and nonetheless appropriate regarding the statistical requirementsof structural equation modelling; as for instance multi-item measurement. 
Zhang et al. (2008, p. 213) analyze, in a review paper, how often the cultural approach is applied in service research and develop a cultural service personality. They use the theory of Schwartz. However, recently only few studies are available; especially with a China focus. Among them, only Xiao and Kim (2009) and Knörle (2011) focus on consumer behaviour, and no study directly targets values towards satisfaction or loyalty aspects. Nonetheless, the constructs that perceived service quality, after-sales service satisfaction, workshop loyalty and brand loyalty are affected by cultural influences is most likely, and indicated by literature. Thereby, the most significant and after-sales context-specific studies are presented in Figure 4.. However, the application of the ten core values in China about the entire after-sales service process chain was not executed in any work. Thus the hypotheses testing in this paper will overcome this limitation, to significantly enrich the body of knowledge.

\section{Research model proposed}

Considering the above conceptual constructs we have built a model based on an aggregate of all mentioned constructs, and their relationships, which are expressed as hypotheses. These are aligned in a path model as depicted in the enclosed Figure 4.

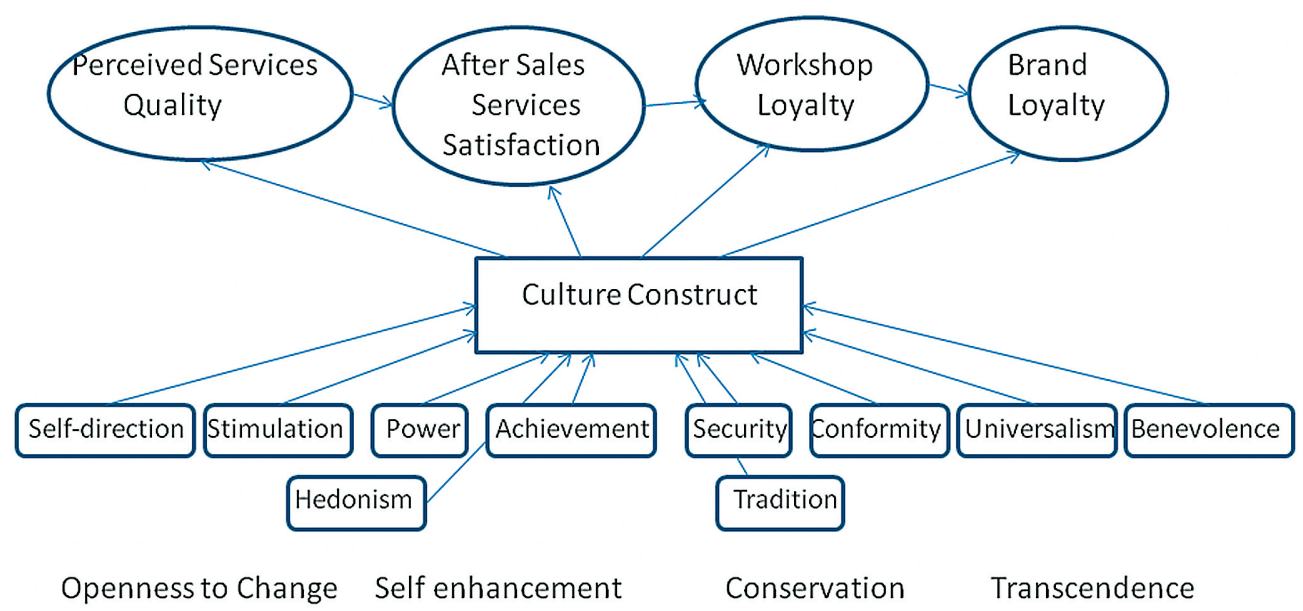

Figure 4: Proposed culture model aligned with Success Value chain (Source: authors)

The culture construct is modelled as a formative-reflective second-order construct. If the ten values were modelled directly, this would lead to a huge complexity and therefore affect the statistical explanation power negatively. (Wetzels et al., 2009, p. 178).For instance, the $\mathrm{R}^{2}$ rises in complex models, when too many paths are pointing toward a targeting construct (Hair et al., 2014, p. 176). The used second-order approach leads to parsimony, without lacking any explanation power, because the causal influence of each level value can be assessed via cumulative effects analysis. Modelling second-order constructs is a sophisticated approach to various requirements. It is too exhaustive to present the process in this paper, but Hair et al. (2014b) provide an excellent introduction to the topic. To explicitly model reflective-formativesecond-orderconstructs, Becker, Klein, and Wetzels (2012) and Wright, Campbell, Thatcher, and Roberts (2012) provide appropriate guidelines.

\section{Empirical Study}

\subsection{Survey Method and Sample}

To gather the required data for the empirical success factor analysis via partial least squares (PLS) structural equation modelling (SEM), a field research was conducted. This approach was carried out through the means of a standardised online questionnaire - containing structured questions with five-point Likert rating scale. It was additionally challenged by two pre-tests, before it was addressed to an automotive panel in China. In sum, 434 Chinese individuals were invited to the survey, which 340 of them took and 330 completed. After the data quality control process, a final data set of 301 cases resulted.This sample is composed of $66 \%$ males and $34 \%$ females, driving a distribution of $57 \%$ Audi, $29 \%$ BMW, and $14 \%$ 
Mercedes-Benz models. Around one-third live in Shanghai, 19\% in Beijing and also 19\% in Guangdong. Consequently, the variety of other places is large (31\%).Thus, in contrast to published studies, where often only students are surveyed (e.g. Knörle, 2012), this sample contains a widespread regional distribution.

\subsection{Research Model Evaluation}

In this study, we are facing a multidimensional construct. To deal with Culture construct, we followed Wright et al. (2012) two-stage approach. In the first stage, we evaluated the reliability validity of the first-order measurement model for our multidimensional latent variable, Culture. Then, in a second step, we assessed a measurement and the structural second order model simultaneously using the latent variable scores of Culture'sdimensions as indicators of themultidimensional construct Culture.

To evaluate PLS-SEM path models, first, the outer measuring models must be assessed. Here, it is crucial to distinguish between reflectively and formative measured constructs (Hair et al., 2014a, p. 109;DiamantopoulosandWinkelhöfer, 2001, pp. 269 et seq.) Afterwards, the structural model is evaluated. If both are assessed as sufficient, the model is appropriate for hypotheses testing.

In this study, all evaluation criteria are very well fulfilled. Thus,for the reflective measuring patterns, internal consistency, convergent validity, and discriminant validity are established. Likewise, for formative measuring models, content validity, multicollinearity among indicators, and the significance and relevance of the outer weights as well as the outer loadings, are assessed as sufficient. Finally, the structural model is evaluated according to multicollinearity testing, $\mathrm{R}^{2}, \mathrm{f}^{2}, \mathrm{Q}^{2}$ and $\mathrm{q}^{2}$ assessments - as pretty good; exceeding all requirements.

\section{Results}

Results for the first and second order measurement models are shownin Table 3.

Table 3: Measurement model.

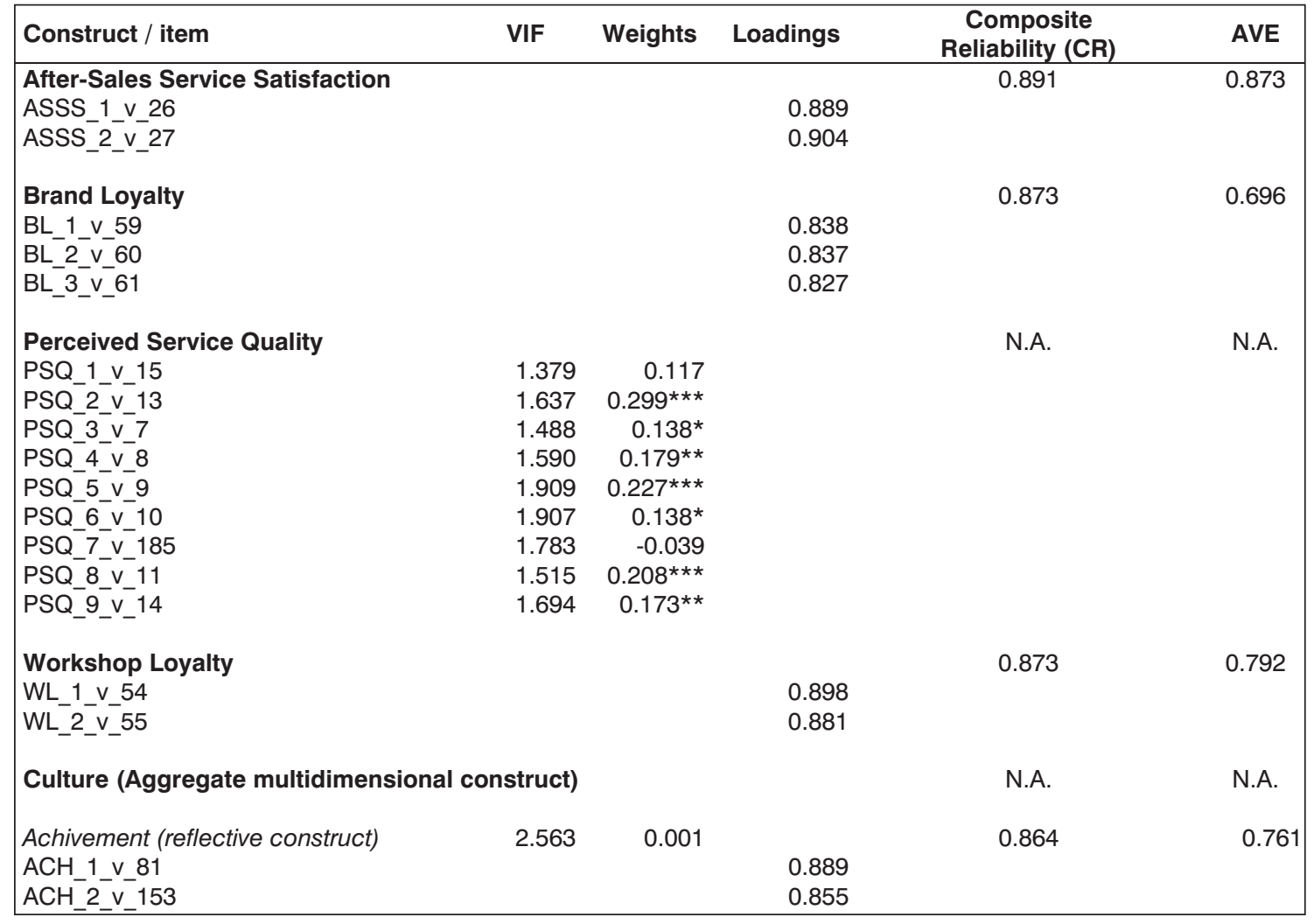




\begin{tabular}{|c|c|c|c|c|c|}
\hline Construct / item & VIF & Weights & Loadings & $\begin{array}{c}\text { Composite } \\
\text { Reliabilitv (CR) }\end{array}$ & AVE \\
\hline Benevolence (reflective construct) & 2.839 & 0.156 & & 0.822 & 0.698 \\
\hline BEN_1_v_152 & & & 0.853 & & \\
\hline BEN_2_v_158 & & & 0.817 & & \\
\hline Conformity (reflective construct) & 2.518 & 0.042 & & 0.847 & 0.698 \\
\hline CON 1 v 84 & & & 0.826 & & \\
\hline CON_2_v_156 & & & 0.887 & & \\
\hline Hedonism (reflective construct) & 2.392 & 0.051 & & 0.884 & 0.792 \\
\hline HED_1_v_87 & & & 0.885 & & \\
\hline HED_2_v_161 & & & 0.895 & & \\
\hline Power (reflective construct) & 1.896 & 0.079 & & 0.838 & 0.721 \\
\hline POW 1 v 79 & & & 0.843 & & \\
\hline POW_2_v_157 & & & 0.856 & & \\
\hline Security & 2.003 & 0.162 & & 0.808 & 0.678 \\
\hline SEC 1 v 82 & & & 0.791 & & \\
\hline SEC_2_v_154 & & & 0.855 & & \\
\hline Self-direction (reflective construct) & 2.448 & $0.257^{*}$ & & 0.859 & 0.753 \\
\hline SE-D $1 \vee 78$ & & & 0.877 & & \\
\hline SE-D_2_v_88 & & & 0.858 & & \\
\hline Stimulation (reflective construct) & 1.729 & 0.112 & & 0.866 & 0.764 \\
\hline STI $1 \vee 83$ & & & 0.874 & & \\
\hline STI_2_v_155 & & & 0.875 & & \\
\hline Tradition (reflective construct) & 1.729 & -0.056 & & 0.835 & 0.716 \\
\hline TRA $1 \vee 86$ & & & 0.877 & & \\
\hline TRA_2_v_160 & & & 0.815 & & \\
\hline Universalism & 2.444 & $0.421 * * *$ & & 0.886 & 0.796 \\
\hline UNI 1 v 80 & & & 0.902 & & \\
\hline UNI'2- v 85 & & & 0.882 & & \\
\hline
\end{tabular}

*** Significant at $p<0.001$, *Significant at $p<0.05$ N.A.: Not applicable.

On the one hand, reflective measures revealed reliable as loading values were above the suggested threshold, 0.707. Internal consistency was evaluated through Composite reliability. Values for all reflective constructs were higher than the recommended cut-off level of 0.7 . We evaluated the convergent validity checking that average variance extracted (AVE) values were above 0.5 (Henseler, Ringle, and Sinkovics, 2009). Finally, discriminant validity was assessed through Fornell-Lacker criterion (Fornelland Larcker, 1981). To ensure discriminant validity, we confirmed that the AVE of each latentvariable is higher than the squared correlations with all other latent variables (see Table 4).

Table 4: Matrix of correlation between latent variables.

\begin{tabular}{|lccccc|}
\hline & $\begin{array}{c}\text { After-Sales } \\
\text { Service } \\
\text { Satisfaction }\end{array}$ & $\begin{array}{c}\text { Brand } \\
\text { Loyalty }\end{array}$ & Culture & $\begin{array}{c}\text { Perceived } \\
\text { Service } \\
\text { Quality }\end{array}$ & $\begin{array}{c}\text { Workshop } \\
\text { Loyalty }\end{array}$ \\
\hline After-Sales Service & $\mathbf{0 . 8 9 7}$ & & & & \\
Satisfaction & 0.623 & $\mathbf{0 . 8 3 4}$ & & & \\
Brand Loyalty & 0.500 & 0.579 & N.A. & & \\
Culture & 0.771 & 0.681 & 0.590 & N.A & 0.890 \\
Perceived Service Quality & 0.744 & 0.684 & 0.543 & 0.752 & \\
Workshop Loyalty &
\end{tabular}

Note: Square root of AVE on diagonals in bold. N.A.: Not applicable. 
On the other hand, we disregarded multicollinearity problems using Variance Inflation Factor (VIF). The VIF values were below the suggested 3.3 thresholds.

Weights show the contribution to the formative construct of each dimension. Table 3 reveals that Universalism (0.421) and Self-direction (0.257) represent the most critical dimensions of Culture.

Additionally, because the perceived service quality is measured formative, we canidentify the most important drivers of this construct. Such findings are particularly relevant, concerning managerial implications, because every item is comparable to the OEM's after-sales service instruments of the marketing mix.

Remarkably, the price or costs, a dimension that is often considered crucial, is not the most important driver for perceived service quality in China. It merely meritsa seventh position out of nine.

The most important aspects are at first convenience (PSQ_2_v_13), with a weight of 0.299, followed by honesty and integrity (0.227)and the third is the appearance of the facility $(0.208)$.

The confirmation of the reliability and validity of the measurement model allowsus the evaluation of the prior proposed relations in the model.

Weassessedthe relationships in the structural model evaluatingthe sign, magnitude, and significance of the path coefficients; the latter using a bootstrapping procedure with 5000 resamples.

Results confirm the relations in the automotive after-sales service success chain modelled ${ }_{3}=0.729$ $\mathrm{p}<0.001,1=0.630 \mathrm{p}<0.001,2=0.524 \mathrm{p}<0.001)$.

Furthermore, we confirmed a significant positive impact of Culture on the Perceived Service Quality $(=0.590$ $p<0.001)$. Workshop Loyalty $(3=0.228 p<0.001)$ and Brand Loyalty $(3=0.294 p<0.001)$. On the contrary, Culture did not have a significant impact on after-sales customer satisfaction.

We assessed the prediction power of our model using the explained variance $\left(R^{2}\right)$. Our results show that the model can explain a substantial amount of the variance for after-sales Customer Satisfaction $\left(R^{2}=0.597\right)$, Workshop Loyalty $\left(R^{2}=0.593\right)$ and Brand Loyalty $\left(R^{2}=0.528\right)$ and a moderate amount of the variance for Perceived Service Quality $\left(R^{2}=0.348\right)$.

The Figure 5 below shows the model proposed contrast with the PLS results.

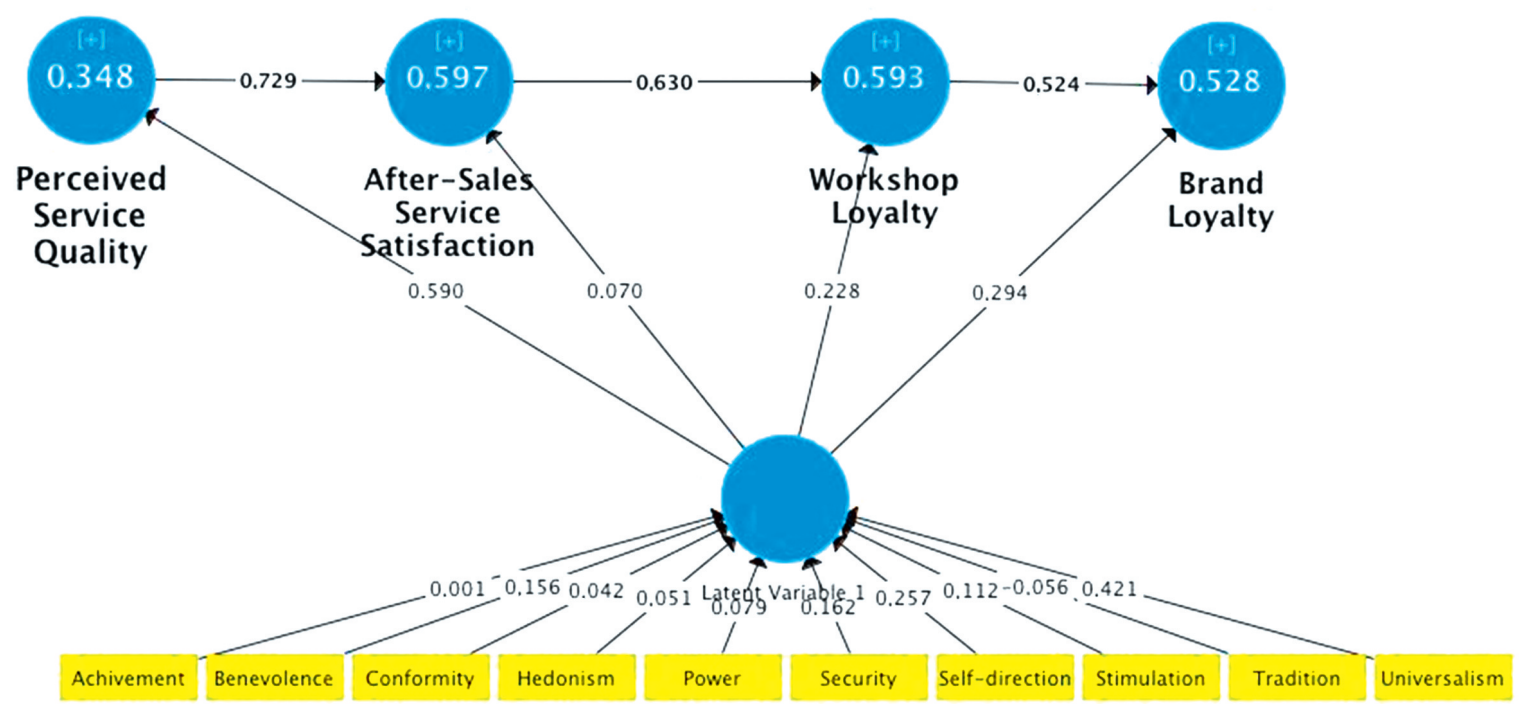

Figure 5: Final PLS model and contrast with Success Value model proposed. 
As the aim of our study is to evaluate the impact of Culture on the after-sales service success, it is interesting to assess the explained variance and the effect size of Culture on the endogenous variables of the model. Results in Table 5 show that Culture can explain a fair amount of the variance on Brand Loyalty (17\%), while its contribution to Workshop Loyalty is lower (12.38\%). These results are also supported by Cohen's $\mathrm{f}^{2}$ values (0.129 and 0.096 respectively) which are considered as small-medium effects (Chin. 1998).

Finally, we reported Stone-Geisser $\mathrm{Q}^{2}$ values obtained through a blindfolding procedure. The $\mathrm{Q}^{2}$ is a criterion of predictive relevance. The $\mathrm{Q}^{2}$ value of latent variables in the PLS path model is obtained by using the blindfolding procedure. The $\mathrm{Q}^{2}$ values over zero presented in Table 4 indicate that our model has sufficient predictive relevance.

Table 5: Effects on endogenous variables.

\begin{tabular}{|c|c|c|c|c|c|}
\hline Effects on endogenous variables & Direct Effects & t-value & $\begin{array}{l}\text { Percentile 95\% } \\
\text { Confidence Interval }\end{array}$ & $\begin{array}{l}\text { Explained } \\
\text { Variance }\end{array}$ & $f^{2}$ \\
\hline \multirow{2}{*}{\multicolumn{6}{|c|}{$\begin{array}{l}\text { Perceived Service Quality } \\
\mathrm{R}^{2}=0.348\end{array}$}} \\
\hline & & & & & \\
\hline Culture & $0.59 * * *$ & 15.41 & {$[0.534,0.683] \mathrm{sig}$.} & $34.8 \%$ & 0.533 \\
\hline \multicolumn{6}{|l|}{ After-Sales Service Satifaction } \\
\hline \multicolumn{6}{|l|}{$R^{2}=0.597 / Q^{2}=0.457$} \\
\hline Perceived Service Quality & $0.729 * * *$ & 17.21 & {$[0.646,8.11] \mathrm{sig}$.} & $56.19 \%$ & 0.861 \\
\hline Culture & 0.07 & 1.38 & {$[-0.028,0.175]$} & $3.51 \%$ & 0.008 \\
\hline \multicolumn{6}{|l|}{ Workshop Loyalty } \\
\hline \multicolumn{6}{|l|}{$R^{2}=0.593 / Q^{2}=0.435$} \\
\hline After-Sales Service Satisfaction & $0.63^{* * *}$ & 12.33 & {$[0.514,0.714] \mathrm{sig}$.} & $46.92 \%$ & 0.732 \\
\hline Culture & $0.228^{* * *}$ & 4.26 & {$[0.135,0.350] \mathrm{sig}$. } & $12.38 \%$ & 0.096 \\
\hline \multicolumn{6}{|l|}{ Brand Loyalty } \\
\hline \multicolumn{6}{|l|}{$R^{2}=0.528 / Q^{2}=0.319$} \\
\hline Workshop Loyalty & $0.524 * * *$ & 10.57 & {$[0.412,0.607] \mathrm{sig}$.} & $35.84 \%$ & 0.411 \\
\hline Culture & $0.294^{* * *}$ & 5.61 & {$[0.195,0.402]$ sig. } & $17 \%$ & 0.129 \\
\hline
\end{tabular}

\section{Limitations}

The paper is based on comprehensive theoretical and conceptual foundations, and assessments are judged cautiously. However, as in every empirical work, limitations exist. Thus the most important ones are presented. First, the focused automobile premium market marks a constraint regarding general disability. Future research should address further segments, such as the low-cost segment. Second, Schwartz's level value theory is introduced as a helpful approach. Thereby, a very effective and time efficient operationalisation approach is applied; nonetheless, further methods exist. Recently, a very fine distinct 19-value approach was presented (Cieciuch et al., 2014a, 2014b; Schwartz et al., 2012,Schwartz, 2011;), which could enrich the scientific body of knowledge by additional insights. However, if the non-cultural (basic) research model is quite complex or resources are limited, the efficient 10-value approach should be favorable. Finally, this paper shows that cultural effects influence important aspects of consumer behavior, butmoderating effects are not considered. Nonetheless, they can be crucial, thus, for instance, gender differences might occur. Some not reported multigroup analyses indicate the existence of moderating effects, which is why future research should focus on that, particularly in relation to the causality of the individual level values. 


\section{Conclusion}

This paper provides a conceptual guideline to analyze automotive after-sales services in China. Thereby, brand loyalty is defined as a success indicator. Moreover, this article introduces an innovative approach to incorporate cultural influences, which are modeled as behavior affecting individual level values.

The results show that brand loyalty is well explained $(52,8 \%)$ by the model's exogenous variables. The proposed after-sales service success chain holds true in China, thus perceived service quality significantly leads to after-sales service satisfaction, which itself is a strong predictor of workshop loyalty. Moreover, workshop loyal customers are likewise significantly brand loyal,

Finally, the influence of culture is empirically verified withthe one exception of after-sales service satisfaction. Furthermore, this paper precisely shows which individual level values are causal. Here, universalism (expresses tolerance of others and the understanding, appreciation, and protection of the welfare) and self-direction (stands for such things as independent thinking, choosing action over inaction, creativity, and exploration) positively contribute to the perception of service quality and loyalty behavior.

\section{REFERENCES}

[1] Asugman, G., Johnson, J. L. and Mc Cullough, J. (1997). The Role of After-Sales Service in International Marketing. Journal of International Marketing, 5 (4), 11-28.

[2] Becker, J. M., Klein, K. and Wetzels, M. (2012). Hierarchical Latent Variable Models in PLS-SEM: Guidelines for Using Reflective-Formative Type Models. Long Range Planning, 45, 359-394. DOI: 10.1016/j.Irp.2012.10.001

[3] Cavalieri, S., Gaiardelli, P. and lerace, S. (2007). Aligning strategic profiles with operational metrics in after-sales service. International Journal of Productivity and Performance Management, 56 (5/6), 436455. DOI:10.1108/17410400710757132

[4] Cieciuch, J. andandDavidov, E. (2012). A comparison of the invariance properties of the PVQ-40 and the PVQ-21 to measure human values across German and Polish Samples. Survey Research Methods, 6 (1), 37-48.

[5] Cui, G. and Liu, Q. (2001). Emerging market segments in a transitional economy: a study of urban consumers in China. Journal of International Marketing, 9 (1), 84-106. DOI:10.1509/jimk.9.1.84.19833

[6] Davidov, E., Schmidt, P. and Schwartz, S. H. (2008). Bringing values back in - The adequacy of the European Social Survey to measure values in 20 countries. Public Opinion Quarterly, 72 (3), 420-445. DOI:10.1093/poq/nfn035

[7] Deng, Z., Lu, Y., Wei, K. K. and Zhang, J. (2010). Understanding customer satisfaction and loyalty: An empirical study of mobile instant messages in China. Internation $\neg$ al Journal of Information Management, 30, 289-300. DOI:10.1016/j.ijinfomgt.2009.10.001

[8] De Mooij, M. (2014). Global Marketing and Advertising: Understanding Cultural Paradoxes, 4.ed., Thousand Oaks et al.: Sage Publications.

[9] Devaraj, S., Matta, K. F. and Conlon, E. (2001). Product And Service Quality: The Antecedents Of Customer Loyalty In The Automotive Industry. Production and Operations Management, 10 (4), 424-439. DOI:10.1111/j.1937-5956.2001.tb00085.x

[10] Diamantopoulos, A., Winkelhofer, H. M. (2001). Index Construction with Formative Indicators: An Alternative to Scale Development, Journal of Marketing Research, 38 (2), 269-277.DOI:10.1509/jmkr.38.2.269.18845

[11] Diez, W. (2009). Automobil-Marketing - NavigationssystemefürneueAbsatzstrategien, E-Book, 5. ed., München: mi-Wirtschaftsbuch/FinanzBuch.

[12] Diez, W., Reindl, S. (2005). "Das Automobilausverkehrs- und politischerSicht. In: Diez, W. et al. (Eds.), Grundlagen der Automobilwirtschaft, 4. ed., 21-69, München: Auto Business Verlag.

[13] Emrich, C. (2014). Interkulturelles Marketing-Management - Erfolgsstrategien, Kozepte, Analysen, 3. ed., Wiesbaden: Springer/Gabler. DOI:10.1007/978-3-658-03033-9

[14] Emrich, C. (2007). Interkulturelles Marketing-Management - Erfolgsstrategien, Ko $\neg$ zepte, Analysen, 2. ed., Wiesbaden: DeutscherUniversitäts-Verlag/GWV Fachverlage.

[15] Engelen, A. and Brettel, M. (2011). A cross-cultural perspective of marketing departments' influence tactics. Journal of International Marketing, 19 (2), 73-94. DOI:10.1509/jimk.19.2.73

[16] Esch, F. R. (2010). Strategie und Technik der Marken-Führung, 6. ed., München: Verlag Franz Vahlen. 
[17] Esch, F.-R. and Isenberg, M. (2013). Markenidentität und Markenpositionierungfestlegen , in: Esch, F.R. (Eds.), Strategie und Technik des Automobilmarketing, 35-57, Wiesbaden: Springer/Gabler. DOI:10.1007/978-3-8349-3831-2_1

[18] Fornell, C. and Larcker, D. F. (1981). Structural equation models with unobservable variables and measurement error: Algebra and statistics. Journal of marketing research, 382-388. DOI:10.2307/3150980

[19] Gallagher, T., Mischke, M. D. and Rogers, M. C. (2005). Profiting from spare parts, McKinsey Quarterly, 2, 1-4.

[20] Gebauer, H., REN, G.-J., Valtakoski, A. and Reynoso, J. (2012). Service-driven manufacturing: provision, evolution and financial impact of services in industrial firms. Journal of Service Manage $\neg$ ment, 23 (1), 120-136. DOI:10.1108/09564231211209005

[21] Goffin, K. (1999). Customer support - A cross-industry study of distribution channels and strategies. International Journal of Physical Distribution and Logistics Management, 29 (6), 374-397. DOI:10.1108/09600039910283604

[22] Goffin, K. and NEW, C. (2001). Customer support and new product development - An exploratory study. International Journal of Operations and Production Management 21 (3), 275-301. DOI:10.1108/01443570110364605

[23] Gong, W. (2003). Chinese consumer behavior: a cultural framework and implications. Journal of American Academy of Business, 3 (1/2), 373-380.

[24] Grönroos, C. (1984). A Service Quality Model and its Marketing Implications. European Journal of Marketing, 18 (4), 36-44. DOI:10.1108/EUM0000000004784

[25] Gudergan, S. (2010). Adoption of technologies in industrial after-sales services across cultures. International Journal of Services Technology and Management, 14 (2/3), 250-258. DOI:10.1504/IJSTM.2010.034331

[26] Hair, J. F. JR., Sarstedt, M., Hopkins, L. and Kuppelwieser, V. G. (2014a). Partial least squares structural equation modeling (PLS-SEM) - An emerging tool in business research. European Business Review, 26 (2), 106-121. DOI:10.1108/EBR-10-2013-0128

[27] Hair, J. F. JR., Hult, G. T. M./Ringle, C. M./Sarstedt, M. (2014b). A Primer on Partial Least Squares Structural Equation Modeling (PLS-SEM), Los Angeles et al.: Sage Publications.

[28] Henseler, J., Ringle, C. M., and Sinkovics, R. R. (2009). The use of partial least squares path modeling in international marketing. In New challenges to international marketing (pp. 277-319). Emerald Group Publishing Limited.

[29] Hofstede, G. (1997). LokalesDenken, globalesHandeln: Kulturen, Zusammenarbeit und Management, München: DeutscherTaschenbuchVerlag.

[30] Huber, F. and Herrmann, A. (2001). A $\neg$ chieving brand and dealer loyalty: the case of the automotive industry. The International Review of Retail, Distribution and Consumer Research, 11 (2), 97-122. DOI:10.1080/713770584

[31] Hull, D. and cox, J. (1994). The field service function in the electronics industry: Providing a link between customers and production/marketing, International Journal of Production Economics, 37 (1), 115-126. DOI:10.1016/0925-5273(94)90012-4

[32] Hunecke, P. (2012). Einfluss von After-Sales-Service Determinanten auf die Marken $\neg$ loyalitätimPremiumautomobilsektor - eineempirischeAnalyse in dreiMärk $\neg$ ten, Göttingen: CuvillierVerlag.

[33] Jonke, R. (2012). Managing after-sales services: strategies and interfirm relationships, Retrieved f rom DOI:10.3929/ethz-a-007307425, accessed 17/5/2013.

[34] Köll, E. (2009). JWT China: Advertising for the New Chinese Consumer. HBS Case, 9-809-079, 1-26.

[35] Knorle, C. (2011). Markenloyalität in China - Kulturelle und markenbeziehungstheoretischeDeterminanten, Berlin: Logos.

[36] Loffler, M. and Decker, R. (2012). Service Satisfaction With Premium Durables: A Cross-Cultural Investigation. In: Diamantopoulos, A. et al. (Eds.), Quantitative Marketing and Marketing Management - Marketing Models and Methods in Theory and Practice, 401-422, Wiesbaden: Gabler. DOI:10.1007/978-3-8349-3722-3_19

[37] Meffert, H., Burrmann, C. and Becker, C. (2010). Internationales Marketing-Management Einmarkenorientierter Ansatz, 4. ed., Stuttgart: Kohlhammer.

[38] Meffert, H. and Bruhn, M. (2009). Dienst $\neg \neg$ leistungsmarketing - Grundlagen - Konzepte - Methoden, Wiesbaden: Gabler.

[39] Muller, S. and Gelbrich, K. (2004). Interkulturelles Marketing, Munchen: Verlag Franz Vahlen. 
[40] Ogba, I.-E. and tan, Z. (2009). Exploring the impact of the brand image on customer loyalty and commitment in China. Journal of Technology Management in China, 4 (2), 132-144. DOI:10.1108/17468770910964993

[41] Osgood, C. E. (1951). Culture: its empirical and non-empirical character. Southwestern Journal of Anthropology, 7 (2), 202-214. DOI:10.1086/soutjanth.7.2.3628623

[42] Reichhuber, A. W. (2010). Strategie und Struktur in der Automobilindustrie - Strategische und organisatorische Programme zur Handhabung automobil wirtschaftlicher Her aus for derungen, Wiesbaden: Gabler.

[43] Saccani, N., Songini, L. and Gaiardelli, P. (2006). The role and performance measurement of after-sales in the durable consumer goods industries: an empirical study. International Journal of Productivity and Performance Management, 55 (3/4), 259-283. DOI:10.1108/17410400610653228

[44] Schwartz, S. H. (2011). Studying Val $\neg$ ues: Personal Adventure, Future Directions. Journal of CrossCultural Psychology, 42 (2), 307-319. DOI:10.1177/0022022110396925

[45] Schwartz, S. H. (2006). A Theory of Cultural Value Orientations: Explication and Applications. Comparative Sociology, 5 (2/3), 137-182. DOI:10.1163/156913306778667357

[46] Schwartz, S. H. (2003). A Proposal for Measuring Value Orientations Across Nations, The European Social Survey (ESS). Retrieved from http://www.europeansoc ialsurvey.org/docs/methodologyy/core_ess questionnaire/ESS_core_questionnaire_human_values.pdf, accessed 01/10/2014, 259-319.

[47] Schwartz, S. H. (1994). Are There Universal Aspects in the Structure and Contents of Human Values?. Journal of Social Issues, 50 (4), 19-45. DOI:10.1111/j.1540-4560.1994.tb01196.x

[48] Schwartz, S. H. (1992). Universals in the content and structure of values: Theoretical advances and empirical tests in 20 countries. Advances in Experimental Social Psychology, 25 (1), 1-65. DOI:10.1016/S0065-2601(08)60281-6

[49] Schwartz, S. H., Cieciuch, J., Vecchione, M., Davidov, E., Fischer, R., Beierlein, C., Ramos, A., Verkasalo, M., Lönnqvist, J.-E., Demirutku, K., Dirilen-Gumus, O. and Konty, M. (2012). Refining the Theory of Basic Individual Values. Journal of Personality and Social Psychology, 103 (4), 663-688. DOI:10.1037/a0029393

[50] Sivadas, E. and Backer-PREWITT, J. L. (2000). An examination of the relationship between service quality, customer satisfaction, and store loyalty. International Journal of Retail and Distribution Management, 28 (2), 73-82. DOI:10.1108/09590550010315223

[51] Sha, S., Huang, T. and Gabardi, E. (2013). Upward Mobility: The future of China's Premium Car Market, McKinsey Automotive and Assembly Practice in Greater China, available online at http://www.mckin seychina.com/2013/03/07/upward-mobility-the-future-of-chinas-premium-car-

[52] Srnka, K. (2005). Marketing.ethik.andkultur. MünchenMering: Rainer HamppVerlag.

[53] Triandis, H. C. (1994). Culture and Social Behaviour, New York et al.: McGraw Hill.

[54] VDA - Verband der Automobilindustrie e. V. (n. a.) (2015). Jahresbericht 2015, available online at https://www.vda.de/de/s services/Publikationen/jahresbericht-2015.ht ml, accessed 26/8/2015.

[55] Wang, Q. (2011). Development and trends of China's automobile market: evidence from urban household ownership of cars, bicycles, motorcycles and motorbikes. International Journal of Automotive Technology and Management, 11 (2), 99-113. DOI:10.1504/IJATM.2011.039539

[56] Wang, A., Liao, W., Hein, A.-P. (2012). Bigger, better, broader: A perspective on China's auto market in 2020. In: McKinseyandCompany (Eds.), Automotive and Assembly Practice, available online at http://c si.mckinsey.com/knowledge_by_region/asia/china/chinas_a uto_market_in_2020, accessed 15/10/2013.

[57] Wetzels, M., Oderkerken-Schröder, G. and Van Oppen, C. (2009). Üsing PLS Path Modeling For Assessing Hierarchical Construct Models: Guidelines And Empirical Illustration. MIS Quarterly, 33 (1), 177-195.

[58] Wise, R. and Baumgartner, P. (1999). Go downstream - The New Profit Imperative in Manufacturing, Harvard Business Review, 77 (5), 133-141.

[59] Wright, R. T., Campbell, D. E., Thatcher, J. B., and Roberts, N. H. (2012). Operationalizing Multidimensional Constructs in Structural Equation Modeling: Recommendations for IS Research.CAIS, 30, 23.

[60] Zhang, J., Beatty, S. E. and Walsh, G. (2008). Review and future directions of cross-cultural consumer services research, Journal of Business Research, 61, 211-224. DOI:10.1016/j.jbusres.2007.06.003 


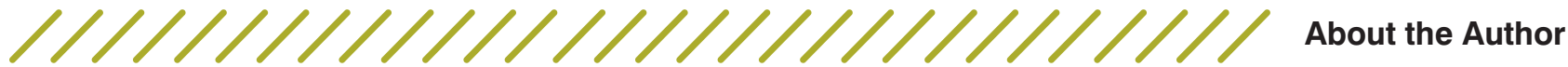

Jose Albors-Garrigos

Universitat Politécnicade Valencia jalbors@doe.upv.es

Emeritus professor at the Universitat Politécnica de Valencia (UPV) in Spain. Dr. Albors is an Industrial engineer from Univ.Pol. de Madrid where he was awarded a $\mathrm{PhD}$ degree and an MBA. With more than 25 years professional experience in engineering Dr. Albors joined UPV in 1995 becoming Full professor in 2010. He has ample academic and research experience in the fields of Innovation and Technology Management as well as Knowledge Management where he has been consultant and researcher. He has published more than 80 articles in international journals and 150 papers in international conferences.

Alexander Frass
Hochschule für Angewandte Wissenschaften Hamburg alexander.frass@mfgabelstapler.de

Alexander Fraß studied social economy and entrepreneurship at the University of Hamburg and the Institute of Technology Tralee (Ireland). In 2015, he completed his dissertation at the Universitat Politecnica de Valencia (Spain) in co-operation with the Hamburg University of Applied Sciences. Since 2016 he is responsible for the marketing and sales activities of a leading forklift dealership in North Germany.

Klaus Peter Schoeneberg Beuth Hochschule für Technik Berlin kpschoeneberg@gmail.com

Klaus-Peter Schoeneberg is a full professor at the Beuth University of Applied Sciences Berlin, Department Business Administration and Social Sciences. His major professional interests include: Analytics, Data Mining, Machine Learning, Automation for Predictive Modelling, Social Media Analytics and Text Analytics.

Angel Peiro Signes UniversitatPolitecnica de Valencia anpeisig@doe.upv.es

Dr.Peiro is Associate Professor at Universitat Politécnica de Valencia (UPV) in Spain. He graduated as Ind. Engineer and has obtained his PhD in Business management form U.P.V. Dr. Peiro has more than 10 years professional experience in engineering and numerous publications in international journals. He is an specialist in PLS and statistical methods.
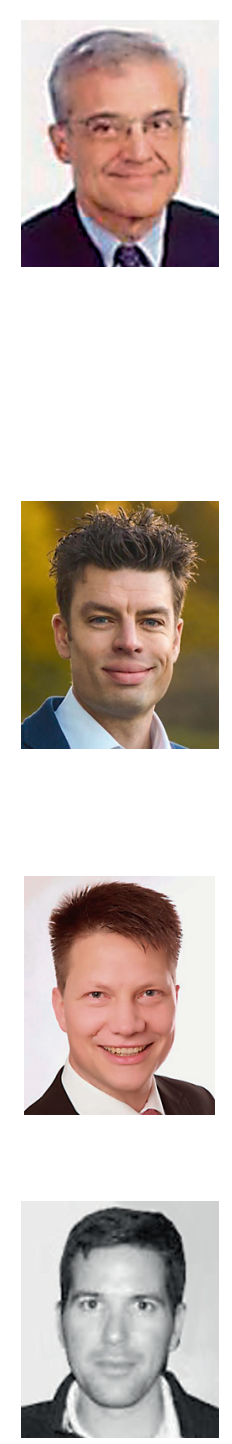